\title{
ANALISIS WAKTU KELULUSAN MAHASISWA FMIPA UNIVERSITAS UDAYANA DAN FAKTOR-FAKTOR YANG MEMENGARUHINYA
}

\author{
I Gusti Ayu Made Srinadi ${ }^{1 \S}$ dan Desak Putu Eka Nilakusmawati ${ }^{2}$ \\ ${ }^{1}$ Program Studi Matematika, FMIPA, Universitas Udayana, Email: srinadi@unud.ac.id \\ ${ }^{2}$ Program Studi Matematika, FMIPA, Universitas Udayana, Email: nilakusmawati@unud.ac.id \\ ${ }^{\S}$ Corresponding Author
}

\begin{abstract}
The graduate profile shows the competencies of the graduate. Not all students are able to complete their studies within the specified study period. Some students are threatened with dropping out (DO) because within the maximum time limit given, which is 7 years for undergraduate degrees, they are still unable to complete their studies. This condition has a negative impact on student graduation on time which negatively affects to the assessment of study program accreditation. To anticipate this condition, it is necessary to know what obstacles students made they are unable to complete their studies on time. The information obtained can be used as a guide in anticipating no more students exceeds study period. The purpose of this study was to determine the graduation of undergraduate students of FMIPA Udayana University and the factors that influence student graduation. The research sample was taken using purposive sampling technique of FMIPA, Udayana University graduation period January 2002 to January 2019. Data analysis used statistics descriptive and exploratory factor analysis. The graduation data of FMIPA undergraduate students, there was 2710 students, 2190 (81\%) was able to complete studies no more than five years and 514 students (19\%) more than five years. There is significant dependency between study period with gender and study program. There are two intellectual factors that influence student graduation not on time, namely the knowledge and skills factor with an explainable diversity of $63.2 \%$.
\end{abstract}

Keywords: Graduate Profile, Competency of Graduates, Exploratory Factor Analysis, Diversity

\section{PENDAHULUAN}

Permenristekdikti RI No. 44 Tahun 2015, diubah dengan Permenristekdikti No 50 Tahun 2018, dan saat ini telah ditetapkan dengan Permendikbud No 3 Tahun 2020 menetapkan Standar Nasional Pendidikan Tinggi (SN Dikti). SN Dikti terdiri atas Standar pendidikan, Standar Penelitian, dan Standar Pengabdian kepada Masyarakat, merupakan satu-kesatuan yang tidak dapat dipisahkan dalam Pelaksanaan Tri Dharma Perguruan Tinggi dan menjamin agar tercapai mutu yang telah ditetapkan. SN Dikti merupakan kriteria minimal yang harus dipenuhi oleh seluruh perguruan tinggi di Indonesia. FMIPA Universitas Udayana juga telah merumuskan Standar Pendidikan Tinggi, mengacu pada Standar Universitas Udayana yang menetapkan standar khusus sebagai pelampauan dari SN Dikti.

Masa studi untuk program strata 1 (S1)
FMIPA Universitas Udayana, sama dengan SN Dikti menetapkan paling lama masa studi S1 adalah 7 tahun akademik dengan beban belajar mahasiswa paling sedikit 144 satuan kredit semester (SKS). Masa studi mahasiswa S1 dengan pemenuhan kompetensi lulusan tidak lebih dari 5 tahun akademik atau 10 semester, dikatakan mahasiswa lulus tepat waktu. Hal ini didasarkan pada waktu penyelesaian studi S1 ideal 4 tahun akademik dan hak pemberhentian sementara (cuti) kuliah seorang mahasiswa maksimal 2 semester.

Prosentase mahasiswa lulus tepat waktu menjadi salah satu kriteria dalam penilaian akreditasi Program Studi, sebagai salah satu indikator apakah standar Proses Pembelajaran yang ditetapkan dalam implementasinya telah terpenuhi. Kerjasama antar civitas akademika Program Studi sangat diperlukan agar 
kompetensi lulusan terpenuhi dan mahasiswa lulus tepat waktu dapat diwujudkan. Kompetensi lulusan mencakup pengetahuan, keterampilan, dan sikap profesionalisme, sesuai dengan salah satu tujuan FMIPA Universitas Udayana yaitu menciptakan lulusan yang berkualitas, mandiri serta mampu berperan aktif dalam aktivitas pembangunan nasional (Pedomak Akademik, 2019). FMIPA Universitas Udayana berupaya menghasilkan mahasiswa dengan prestasi baik dan dapat menyelesaian studi tepat waktu.

Berdasarkan informasi dari monitoring dan evaluasi kelulusan mahasiswa Universitas Udayana, cukup banyak ditemukan mahasiswa S1 dengan kelulusan tidak tepat waktu, menyelesaikan studinya lebih dari 10 semester. Monitoring terhadap 6 program studi S1 pada FMIPA Universitas Udayana, dipaparkan jumlah atau persentase kelulusan mahasiswa tepat waktu dan tidak tepat waktu, serta rataan hasil belajar mahasiswa berdasarkan indeks prestasi kumulatif (IPK) pada masing-masing program studi.

Masa atau lama studi merupakan waktu yang dibutuhkan mahasiswa untuk menyelesaikan pendidikan di perguruan tinggi. Ada banyak faktor yang menyebabkan mahasiswa lama menyelesaikan studi, faktor internal dan faktor eksternal dari diri mahasiswa. Wahyu (2010) menyatakan faktor internal penyebab lamanya masa studi antara lain: 1) kuliah karena keterpaksaan, dan 2) salah memilih jurusan. Sedangkan faktor eksternal peyebab lamanya masa studi mahasiswa antara lain: 1) terlalu menikmati kebebasan karena jauh dari orang tua, 2) terlalu aktif mengikuti kegiatan organisasi kemahasiswaan, 3) menekuni hobi secara berlebihan, 4) bekerja sambilan, dan 5) tidak ada jaminan mendapat pekerjaan setelah lulus.

Satiman, dkk (2015) menguraikan faktorfaktor yang berperan dalam proses pembelajaran meliputi: a) faktor intelektual adalah kemampuan seseorang yang diperlihatkan melalui kecerdasan dan kepandaiannya dalam berpikir dan berbuat, seperti bakat, kapasitas belajar, kecerdasan intelektual (IQ), dan hasil belajar yang telah dicapai; b) faktor nonintelektual adalah segala kondisi dari dalam dan luar dirinya atau lingkungan sekitar yang terkait dengan diri seorang dalam memengaruhi kemampuan berpikir dan bertindak, seperti masalah belajar, sosial, keuangan, keluarga, organisasi, sahabat, metode belajar, serta lingkungan. Faktor intelektual yaitu kecerdasan intelegensi dalam proses pembelajaran berperan terutama dalam aspek kognitif seperti hasil nilai ulangan harian, dan nilai ujian semester. Faktor intelektual yang lain seperti kecerdasan emosional, kecerdasan spiritual, dan kecerdasan kesuksesan merupakan aspek afektif dalam proses pembelajaran.

Terkait faktor kecerdasan intelegensi dalam aspek kognitif, hasil belajar ditunjukkan dari nilai ulangan, ujian semester, indeks prestasi semester (IPS), atau indeks prestasi kumulatif. Untuk mahasiswa S1 FMIPA Universitas Udayana, IPS merupakan hasil belajar yang dicapai mahasiswa dalam satu semester, menunjukkan penguasaan mahasiswa terhadap pengetahuan atau ketrampilan yang ditetapkan dalam mata kuliah-mata kuliah semester tersebut. Pengetahuan meliputi pengetahuan konsep dasar dan konsep lanjutan yang mendukung mahasiswa memiliki ketrampilan umum dan ketrampilan khusus seperti ditetapkan dalam standar kompetensi.

Penelitian ini bertujuan mengetahui waktu kelulusan mahasiswa S1 FMIPA Universitas Udayana dan mengetahui faktor intelektual yang memengaruhi kelulusan mahasiswa tidak tepat waktu.

Faktor intelektual pada penelitian ini adalah hasil belajar pada tiap semester (IPS1, IPS2, IPS3, IPS4, IPS5, IPS6, dan IPS7), serta IPK. Hasil belajar ini menggambarkan pengetahuan konsep dasar, pengetahuan konsep keahlian, ketrampilan umum, dan ketrampilan khusus yang dikuasai mahasiswa. Penentuan faktor dari indikator-indikator penyusunnya dianalisis dengan menggunakan analisis faktor.

Tujuan dari analisis faktor adalah untuk menggambarkan hubungan-hubungan kovarian antara beberapa variabel yang mendasari tetapi tidak teramati dan kuantitas random yang disebut faktor (Johnson \& Wichern, 1998) dan (Hair et.al., 1995). Vektor random teramati $\boldsymbol{X}$ dengan $p$ komponen, memiliki rata-rata $\boldsymbol{\mu}$ dan matriks kovarian $\sum$. Model faktor mendalilkan bahwa $\boldsymbol{X}$ secara linier bergantung pada beberapa variabel acak tidak teramati $F_{1}, F_{2}, \ldots, F_{m}$ yang disebut common faktor dan $p$ sumber variasi tambahan $\varepsilon_{1}, \varepsilon_{2}, \ldots, \varepsilon_{p}$ yang disebut galat atau faktor spesifik. Model analisis faktor dinyatakan sebagai

$$
\begin{gathered}
X_{1}-\mu_{1}=l_{11} F_{1}+l_{12} F_{2}+\cdots+l_{1 m} F_{m}+\varepsilon_{1} \\
X_{2}-\mu_{2}=l_{21} F_{1}+l_{22} F_{2}+\cdots+l_{2 m} F_{m}+\varepsilon_{2} \\
\vdots \quad \vdots \\
X_{p}-\mu_{p}=l_{p 1} F_{1}+l_{p 2} F_{2}+\cdots+l_{p m} F_{m}+\varepsilon_{p}
\end{gathered}
$$


atau dapat ditulis dalam notasi matriks sebagai berikut:

$$
\underset{(p \times 1)}{\boldsymbol{X}-\boldsymbol{\mu}}=\underset{(p \times m)}{\boldsymbol{L}} \underset{(m \times 1)}{\boldsymbol{F}}+\underset{(p \times 1)}{\boldsymbol{\varepsilon}}
$$

dengan $l_{i j}$ adalah loading dari variabel ke-i pada faktor ke-j, dan matriks $\boldsymbol{L}$ disebut sebagai matriks faktor loading. Faktor spesifik $\varepsilon_{i}$ dikaitkan hanya dengan respon $X_{i}$. Simpangan $X_{1}-\mu_{1}, X_{2}-\mu_{2}, \ldots, X_{p}-\mu_{p}$ dinyatakan dalam $p+m$ variabel $F_{1}, F_{2}, \ldots, F_{m}, \varepsilon_{1}, \varepsilon_{2}, \ldots, \varepsilon_{p}$ yang tidak teramati (Johnson \&Wichern, 1998).

Vektor acak tidak teramati $\boldsymbol{F}$ dan $\boldsymbol{\varepsilon}$ memenuhi kondisi: 1) $\boldsymbol{F}$ dan $\boldsymbol{\varepsilon}$ saling bebas, 2) $E(\boldsymbol{F})=\mathbf{0}, \operatorname{Cov}(\boldsymbol{F})=I, E(\boldsymbol{\varepsilon})=\mathbf{0}, \operatorname{Cov}(\boldsymbol{\varepsilon})=\boldsymbol{\psi}$ dengan $\boldsymbol{\psi}$ adalah matriks diagonal. Penguraian matirks covarian $\boldsymbol{\Sigma}$ dinyatakan pada persamaan (2).

$$
\begin{gathered}
\boldsymbol{\Sigma}=\operatorname{Cov}(\boldsymbol{X})=E(\boldsymbol{X}-\boldsymbol{\mu})(\boldsymbol{X}-\boldsymbol{\mu})^{\prime}=\boldsymbol{L L}^{\prime}+\boldsymbol{\psi} \\
\operatorname{Var}\left(X_{i}\right)=l_{i 1}^{2}+l_{i 2}^{2}+\cdots+l_{i m}^{2}+\psi_{i} \\
\operatorname{Cov}\left(X_{i}, X_{k}\right)=l_{i 1} l_{k 1}+l_{i 2} l_{k 2}+\cdots+l_{i m} l_{k m}
\end{gathered}
$$

Bagian dari variansi variabel ke- $i$ pada $m$ common faktor disebut komunalitas ke- $i$ yang merupakan jumlah kuadrat dari loading variabel ke- $i$ pada $m$ common faktor (Johnson \&Wichern, 1998), dinyatakan pada persamaan (3).

$$
\underbrace{\sigma_{i i}}_{\operatorname{Var}\left(X_{i}\right)}=\underbrace{l_{i 1}^{2}+l_{i 2}^{2}+\cdots+l_{i m}^{2}}_{\text {communality }+ \text { specific variance }}+\underbrace{\psi_{i}}_{i}
$$

Dengan $h_{i}^{2}=l_{i 1}^{2}+l_{i 2}^{2}+\cdots+l_{i m}^{2}$, maka

$$
\sigma_{i i}=h_{i}^{2}+\psi_{i} ; i=1,2, \ldots, p
$$

Matirks covarian $\boldsymbol{\Sigma}$ memiliki pasangan nilai eigen dan vektor eigen $\left(\lambda_{i}, e_{i}\right)$ dengan $\lambda_{1} \geq$ $\lambda_{2} \geq \cdots \geq \lambda_{p} \geq 0$ dan untuk $\psi_{i}=0$ maka

$$
\begin{gathered}
\boldsymbol{\Sigma}=\lambda_{1} e_{1} e_{1}^{\prime}+\lambda_{2} e_{2} e_{2}^{\prime}+\cdots+\lambda_{p} e_{p} e_{p}^{\prime}= \\
{\left[\sqrt{\lambda_{1}} e_{1}: \sqrt{\lambda_{2}} e_{2}: \cdots: \sqrt{\lambda_{p}} e_{p}\right]\left[\begin{array}{c}
\sqrt{\lambda_{1}} e_{1}{ }^{\prime} \\
\sqrt{\lambda_{2}} e_{2} \\
\vdots \\
\sqrt{\lambda_{p}} e_{p}^{\prime}
\end{array}\right]}
\end{gathered}
$$

Analisis faktor dengan komponen utama dari matriks kovarian sampel $\boldsymbol{S}$ ditetapkan memiliki pasangan nilai eigen dan vektor eigen $\left(\hat{\lambda}_{l}, \hat{e}_{i}\right)$ dan $\hat{\lambda}_{1} \geq \hat{\lambda}_{2} \geq \cdots \geq \hat{\lambda}_{p}$. Misalkan untuk $m<p$ menyatakan banyak common faktor maka estimasi matriks faktor loading $\tilde{L}=\left\{\tilde{l}_{i j}\right\}$ diberikan oleh (Johnson \&Wichern, 1998)

$$
\tilde{L}=\left[\sqrt{\hat{\lambda}_{1}} \hat{e}_{1}: \sqrt{\hat{\lambda}_{2}} \hat{e}_{2}: \cdots: \sqrt{\hat{\lambda}_{m}} \hat{e}_{m}\right]
$$

Penduga dari variansi spesifik adalah unsur diagonal utama dari matriks $\boldsymbol{S}-\tilde{\boldsymbol{L}} \widetilde{\boldsymbol{L}}^{\prime}$, sehingga

$$
\widetilde{\boldsymbol{\psi}}=\left[\begin{array}{cccc}
\tilde{\psi}_{1} & 0 & \ldots & 0 \\
0 & \tilde{\psi}_{2} & \ldots & 0 \\
\vdots & \vdots & \ddots & \vdots \\
0 & 0 & \cdots & \tilde{\psi}_{p}
\end{array}\right]
$$

dengan $\tilde{\psi}_{\mathbf{1}}=s_{i i}-\sum_{j=1}^{m} \tilde{l}_{i j}^{2}$.

Komunalitas diestimasi dengan

$$
\tilde{h}_{i}^{2}=\tilde{l}_{i 1}^{2}+\tilde{l}_{i 2}^{2}+\cdots+\tilde{l}_{i m}^{2}
$$

Secara ideal, kontribusi beberapa faktor pertama terhadap variansi sampel semestinya mendekati 1. Kontrbusi common faktor pertama pada variansi sampel $S_{i i}$ dinyatakan sebagai $\tilde{l}_{i 1}^{2}$. Kontribusi terhadap total variansi sampel $S_{11}+S_{22}+\cdots+S_{p p}=\operatorname{tr}(S)$, untuk common faktor pertama yaitu

$$
\begin{aligned}
\tilde{l}_{11}^{2}+\tilde{l}_{21}^{2}+\cdots+\tilde{l}_{p 1}^{2} & =\left(\sqrt{\hat{\lambda}_{1}} \hat{e}_{1}\right) \cdot\left(\sqrt{\hat{\lambda}_{1}} \hat{e}_{1}\right) \\
& =\hat{\lambda}_{1}
\end{aligned}
$$

(Johnson \&Wichern, 1998)

\section{METODE PENELITIAN}

Informasi mengenai waktu kelulusan mahasiswa S1 FMIPA Universitas Udayana diperoleh dari hasil analisis statistika deskriptif data kelulusan mahasiswa yang mengikuti wisuda pada periode Januari 2002 hingga Januari 2019, atau dalam periode tersebut tidak menyelesaikan studinya (berhenti kuliah). Data kelulusan mahasiswa diperoleh dari basis data pada operator SIMAK FMIPA Universitas Udayana. Tercatat 2710 mahasiswa S1 pada keenam program studi di lingkungan FMIPA Universitas Udayana.

Sesuai dengan kelulusan tepat waktu mahasiswa S1 yang ditetapkan Universitas Udayana, yaitu mahasiswa yang mampu menyelesaikan studinya tidak lebih dari 10 semester, disarikan kelulusan mahasiswa tepat waktu dan tidak tepat waktu menurut jenis kelamin dan program studi.

Untuk mengetahui faktor intelektual yang memengaruhi mahasiswa menyelesaikan studi tidak tepat waktu, diambil 150 sampel mahasiswa dengan kelulusan tidak tepat waktu dengan pertimbangan kecukupan dan kelengkapan data untuk dianalisis dengan analisis faktor. Variabel penelitian ditetapkan berdasarkan informasi data populasi mahasiswa S1 FMIPA Universitas Udayana, signifikansi korelasi linear antara lama atau masa studi, IPK, 
dan total SKS yang diprogram mahasiswa, dikembangkan dengan melihat indeks prestasi dalam tiap semester (IPS) mahasiswa. Hal ini mempertimbangkan capaian pembelajaran (CP) atau Learning Outcome (LO) serta kompetensi yang diharapkan mampu dicapai mahasiswa dalam pembelajaran mata kuliah pada setiap semester. Kompetensi yang dikuasai mahasiswa dapat dipilah menjadi kompetensi awal (penguasaan terhadap konsep-konsep dasar) yang biasanya diberikan pada semester 1 dan 2 . Semester 3 dan semester 4 mahasiswa diharapkan menguasai konsep-konsep menuju bidang keahlian, dan semester selanjutnya dirancang mahasiswa mampu mengelaborasi keahliannya dengan lebih fokus pada kapitakapita selekta sesuai minat dan keahlian. Atas pertimbangan tersebut sebagai indikator capaian kompetensi yang tergolong faktor intelektual dari mahasiswa didasarkan pada nilai IPS pada semester 1 hingga semester 7, IPK, dan total SKS dijadikan sebagai variabel penelitian.

Langkah-langkah dalam penentuan faktor dengan analisis faktor ekploratori dengan metode komponen utama adalah

1. Menentukan matriks korelasi variabel

2. Menentukan banyak komponen dengan nilai eigen lebih besar atau sama dengan satu

3. Melakukan analisis faktor dengan banyak faktor dari hasil rekomendasi pada langkah 2

4. Melakukan rotasi ortogonal pada loading faktor untuk menentukan variabel-variabel intelektual yang membentuk faktor, sebagai rujukan dalam penamaan faktor

5. Menginterpretasikan faktor-faktor yang memengaruhi mahasiswa menyelesaikan studi tidak tepat waktu.

\section{HASIL DAN PEMBAHASAN}

\subsection{Deskripsi Kelulusan Mahasiswa}

Data 2710 mahasiswa S1 FMIPA Universitas Udayana menurut waktu kelulusan (lama semester), Indeks Prestasi Kumulatif (IPK), dan total satuan kredit semester (SKS) disarikan dalam statistika deskriptif pada Tabel 3.1 .

Tabel 3.1 Kelulusan Mahasiswa FMIPA

\begin{tabular}{|l|l|l|l|l|}
\hline Variabel & Rataan & Stdev & Min & Maks \\
\hline Waktu & 9,4808 & 2,9027 & 6 & 38 \\
\hline IPK & 3,2137 & 0,2917 & 1,9900 & 3,97 \\
\hline SKS & 145,79 & 3,89 & 119 & 171 \\
\hline
\end{tabular}

Sumber: data diolah (2019)
Rataan waktu kelulusan mahasiswa S1 FMIPA Universitas Udayana berada dalam kategori kelulusan tepat waktu, dengan lulus tercepat dalam 6 semester berjalan dan waktu terlama 38 semester. Jumlah sks minimum 119 menunjukkan mahasiswa tersebut belum memenuhi jumlah sks minimum yang harus diambil untuk menjadi sarjana S1. Penelusuran mendalam ditemukan bahwa mahasiswa bersangkutan tidak menyelesaiakan studinya di FMIPA Universitas Udayana, namun datanya tetap tercantum dalam basis data. Ada beberapa mahasiswa memiliki kasus seperti ini, akan memberi dampak negatif dalam perhitungan rataan lama studi mahasiswa. Untuk mengatasi dampak negatif ini, perlu dilakukan sinkronisasi data mahasiswa sehingga mahasiswa yang sudah pasti menghentikan studinya dapat dihapus dalam basis data. Jumlah dan persentase kelulusan mahasiswa S1 FMIPA Universitas Udayana periode wisuda Januari 2002 hingga Januari 2019 diuraikan pada Tabel 3.2.

Tabel 3.2 Jumlah Kelulusan dalam Semester

\begin{tabular}{|c|c|c|c|}
\hline Semester & Jumlah & Persentase & $\begin{array}{l}\text { Persentase } \\
\text { Kumulatif }\end{array}$ \\
\hline Valid 6.00 & 1 & .0 & .0 \\
\hline 7.00 & 66 & 2.4 & 2.5 \\
\hline 8.00 & 1151 & 42.5 & 44.9 \\
\hline 9.00 & 642 & 23.7 & 68.6 \\
\hline 10.00 & 336 & 12.4 & 81.0 \\
\hline 11.00 & 210 & 7.7 & 88.8 \\
\hline 12.00 & 112 & 4.1 & 92.9 \\
\hline 13.00 & 71 & 2.6 & 95.5 \\
\hline 14.00 & 36 & 1.3 & 96.9 \\
\hline 15.00 & 20 & .7 & 97.6 \\
\hline 16.00 & 23 & .8 & 98.5 \\
\hline 17.00 & 9 & .3 & 98.8 \\
\hline 18.00 & 1 & .0 & 98.8 \\
\hline 19.00 & 1 & .0 & 98.9 \\
\hline 20.00 & 2 & .1 & 98.9 \\
\hline 21.00 & 2 & .1 & 99.0 \\
\hline 22.00 & 1 & .0 & 99.0 \\
\hline 23.00 & 2 & .1 & 99.1 \\
\hline 24.00 & 2 & .1 & 99.2 \\
\hline 26.00 & 1 & .0 & 99.2 \\
\hline 28.00 & 1 & .0 & 99.3 \\
\hline 32.00 & 8 & .3 & 99.6 \\
\hline 34.00 & 4 & .1 & 99.7 \\
\hline 36.00 & 4 & .1 & 99.9 \\
\hline 38.00 & 4 & .1 & 100.0 \\
\hline Total & 2710 & 100.0 & \\
\hline
\end{tabular}

Sumber: data diolah (2019) 
Sebagian besar mahasiswa S1 FMIPA Universitas Udayana yaitu $42,5 \%$ menyelesaikan studinya dalam 8 semester, persentase kumulatif mahasiswa lulus tepat waktu sebesar $81 \%$. Angka ini menunjukkan belum terpenuhi tingkat kelulusan mahasiswa tepat waktu yang ditetapkan berdasarkan kontrak kinerja Dekan FMIPA dengan Rektor Universitas Udayana, minimal mahasiswa menyelesaikan studi tepat waktu sebanyakr 90\%. Beberapa mahasiswa dengan masa studi sangat panjang, karena saat itu belum dilaksanakan sistem DO, mengakibatkan rataan masa studi sebesar 9,48 semester meskipun 42,5\% mahasiswa lulus dalam 8 semester. Hal ini menunjukkan adanya kemenjuluran data ke kanan dengan beberapa mahasiswa yaitu $3,1 \%$ (84 orang) menyelesaikan studinya lebih dari 7 tahun.

Jumlah kelulusan tiap semester menurut jenis kelamin mahasiswa dinyatakan dalam tabulasi silang antara jenis kelamain dan lama studi dalam Tabel 3.3.

Tabel 3.3 Tabulasi Silang Jenis Kelamin dan Lama Studi

\begin{tabular}{|c|c|c|c|}
\hline \multirow[b]{2}{*}{ Lama } & \multicolumn{2}{|c|}{ Gender } & Total \\
\hline & Laki & Perempuan & \\
\hline 6.00 & 0 & 1 & 1 \\
\hline 7.00 & 22 & 44 & 66 \\
\hline 8.00 & 332 & 819 & 1151 \\
\hline 9.00 & 285 & 357 & 642 \\
\hline 10.00 & 179 & 157 & 336 \\
\hline 11.00 & 127 & 83 & 210 \\
\hline 12.00 & 69 & 43 & 112 \\
\hline 13.00 & 32 & 39 & 71 \\
\hline 14.00 & 22 & 14 & 36 \\
\hline 15.00 & 10 & 10 & 20 \\
\hline 16.00 & 12 & 11 & 23 \\
\hline 17.00 & 6 & 3 & 9 \\
\hline 18.00 & 1 & 0 & 1 \\
\hline 19.00 & 0 & 1 & 1 \\
\hline 20.00 & 0 & 2 & 2 \\
\hline 21.00 & 2 & 0 & 2 \\
\hline 22.00 & 0 & 1 & 1 \\
\hline 23.00 & 0 & 2 & 2 \\
\hline 24.00 & 2 & 0 & 2 \\
\hline 26.00 & 1 & 0 & 1 \\
\hline 28.00 & 1 & 0 & 1 \\
\hline 32.00 & 1 & 7 & 8 \\
\hline 34.00 & 0 & 4 & 4 \\
\hline 36.00 & 1 & 3 & 4 \\
\hline 38.00 & 1 & 3 & 4 \\
\hline Total & 1106 & 1604 & 2710 \\
\hline
\end{tabular}

Chi-Square Tests

\begin{tabular}{|l|r|r|r|}
\hline & Value & df & $\begin{array}{r}\text { Asymp. Sig. } \\
\text { (2-sided) }\end{array}$ \\
\hline Pearson Chi- & 180.7 & 24 & .000 \\
Square & $59^{\mathrm{a}}$ & 24 & \\
Likelihood Ratio & 188.6 & 24 & .000 \\
& 97 & & \\
N of Valid Cases & 2710 & & \\
\hline
\end{tabular}

Sumber: data diolah (2019)

Mahasiswa S1 FMIPA Universitas Udayana lebih banyak berjenis kelamin perempuan, dan untuk kelulusan juga lebih banyak perempuan yang masa studinya tepat waktu. Hal ini didukung oleh hasil yang signifikan adanya ketergantungan antara variabel masa studi dan jenis kelamin. Ini menunjukkan bahwa mahasiswa perempuan cenderung lebih banyak yang mampu menyelesaikan studinya tepat waktu. Kelulusan mahasiswa laki-laki S1 FMIPA berjumlah 1106 orang $(40,8 \%)$ dan perempuan berjumlah 1604 orang $(59,2 \%)$. Tabel 3.2 dan Tabel 3.3 dapat diringkas menurut standar masa studi S1(4-5) tahun, dikelompokan dalam dua kategori masa studi yaitu tidak lebih dari 5 tahun dan lebih dari 5 tahun dalam Tabel 3.4.

Tabel 3.4. Tabulasi Jenis Kelamin dan Kategori Lama Studi

\begin{tabular}{crcc}
\hline Masa_Studi & Laki-laki & Perempuan & Total \\
\hline Tidak lebih & 818 & 1378 & 2196 \\
5 tahun & $(73,96 \%)$ & $(85,91 \%)$ & \\
Lebih dari & 288 & 226 & 514 \\
5 tahun & $(26,04 \%)$ & $(14,09 \%)$ & \\
Total & 1106 & 1604 & 2710
\end{tabular}

Sumber: data diolah (2019)

Tabulasi silang masa studi mahasiswa S1 FMIPA Universitas Udayana menurut program studi disajikan pada Tabel 3.5.

Ada perbedaan signifikan jumlah kelulusan mahasiswa dalam masa studi pada masingmasing program studi. Hal ini mengindikasikan adanya kebergantungan antara jumlah kelulusan dengan program studi, ada program studi tertentu jumlah kelulusannya berbeda secara signifikan pada masa studi tertentu dengan program studi lainnya. Program studi Matematika belum ada mahasiswanya mencapai kelulusan dalam masa studi kurang dari delapan semester. Program studi Ilmu Komputer mempunyai seorang mahasiswa yang menyelesaiakan studinya dalam 6 semester. Program studi Farmasi memiliki jumlah kelulusan tepat waktu paling tinggi, dan program 
studi Kimia jumlah mahasiswa dengan masa studi lebih dari 32 semester paling banyak

Tabel 3.5 Tabulasi Silang Masa Studi dan Prodi

\begin{tabular}{|c|c|c|c|c|c|c|c|}
\hline \multirow{2}{*}{$\begin{array}{l}\text { La- } \\
\text { ma } \\
\text { (smt } \\
\text { ) }\end{array}$} & \multicolumn{6}{|c|}{ Prodi } & \multirow{2}{*}{$\begin{array}{l}\text { Tot- } \\
\text { al }\end{array}$} \\
\hline & Bio & Far & Fis & Kim & Mat & Ilko & \\
\hline 6 & 0 & 0 & 0 & 0 & 0 & 1 & 1 \\
\hline 7 & 10 & 17 & 3 & 10 & 0 & 26 & 66 \\
\hline 8 & 18 & 47 & & 23 & 13 & 10 & 11 \\
\hline & 5 & 7 & 12 & 9 & 1 & 7 & 51 \\
\hline 9 & 73 & 10 & 66 & 98 & 14 & 15 & 64 \\
\hline & & 2 & 00 & & 6 & 7 & 2 \\
\hline 10 & 35 & 19 & 29 & 48 & 10 & 99 & 33 \\
\hline 11 & & & & & & & 21 \\
\hline & 19 & 12 & 31 & 13 & 64 & 71 & 0 \\
\hline 12 & 4 & 8 & 29 & 8 & 38 & 25 & 11 \\
\hline 13 & 10 & 1 & 10 & 9 & 23 & 18 & $\begin{array}{r}2 \\
71\end{array}$ \\
\hline 14 & 2 & 2 & 5 & 4 & 9 & 14 & 36 \\
\hline 10 & 6 & 2 & 6 & 4 & 0 & 2 & 20 \\
\hline 16 & 3 & 3 & 6 & 2 & 7 & 2 & 23 \\
\hline 17 & 2 & 2 & 1 & 4 & 0 & 0 & 9 \\
\hline 18 & 0 & 0 & 1 & 0 & 0 & 0 & 1 \\
\hline 19 & 0 & 0 & 1 & 0 & 0 & 0 & 1 \\
\hline 20 & 0 & 0 & 1 & 0 & 1 & 0 & 2 \\
\hline 21 & 2 & 0 & 0 & 0 & 0 & 0 & 2 \\
\hline 22 & 0 & 0 & 0 & 1 & 0 & 0 & 1 \\
\hline 23 & 0 & 0 & 2 & 0 & 0 & 0 & 2 \\
\hline 24 & 1 & 0 & 0 & 0 & 1 & 0 & 2 \\
\hline 26 & 1 & 0 & 0 & 0 & 0 & 0 & 1 \\
\hline 28 & 0 & 1 & 0 & 0 & 0 & 0 & 1 \\
\hline 32 & 0 & 0 & 0 & 7 & 1 & 0 & 8 \\
\hline 34 & 0 & 0 & 0 & 4 & 0 & 0 & 4 \\
\hline 36 & 0 & 0 & 1 & 3 & 0 & 0 & 4 \\
\hline 38 & 0 & 0 & 0 & 4 & 0 & 0 & 4 \\
\hline Tot- & 35 & 64 & 20 & 45 & 52 & 52 & 27 \\
\hline al & 3 & 6 & 4 & 8 & 7 & 2 & 10 \\
\hline
\end{tabular}

\begin{tabular}{|l|r|c|c|}
\hline & \multicolumn{1}{|c|}{ Value } & df & $\begin{array}{c}\text { Asymp. } \\
\text { Sig. (2- } \\
\text { sided) }\end{array}$ \\
\hline Pearson Chi-Square & $942.944^{\mathrm{a}}$ & 120 & .000 \\
Likelihood Ratio & 941.144 & 120 & .000 \\
N of Valid Cases & 2710 & & \\
\hline
\end{tabular}

Sumber: data diolah (2019)

Secara keseluruhan, mahasiswa paling banyak menyelesaikan studinya dalam delapan semester, disusul sembilan semester dan sepuluh semester dengan total untuk ketiga semester tersebut sebesar $81 \%$. Sisanya sebesar 19\% dengan masa studi lebih dari 5 tahun.

Masa studi, IPK, dan total SKS mahasiswa menunjukkan korelasi yang signifikan seperti diuraikan dalam Tabel 3.6.
Tabel 3.6 Korelasi Masa Studi, IPK, dan SKS

\begin{tabular}{|c|c|c|c|c|}
\hline & & $\begin{array}{l}\text { Masa } \\
\text { Studi }\end{array}$ & IPK & SKS \\
\hline \multirow[t]{3}{*}{$\begin{array}{l}\text { Masa } \\
\text { Studi }\end{array}$} & $\begin{array}{l}\text { Pearson } \\
\text { Correlation }\end{array}$ & 1 & $.359^{-{ }^{* *}}$ & \\
\hline & Sig. (2-tailed) & & .000 & .000 \\
\hline & $\mathrm{N}$ & 2710 & 2710 & 2710 \\
\hline \multirow[t]{3}{*}{ IPK } & $\begin{array}{l}\text { Pearson } \\
\text { Correlation }\end{array}$ & $-.359^{* * *}$ & 1 & $.308^{* *}$ \\
\hline & Sig. (2-tailed) & .000 & & .000 \\
\hline & $\mathrm{N}$ & 2710 & 2710 & 2710 \\
\hline \multirow[t]{3}{*}{ SKS } & $\begin{array}{l}\text { Pearson } \\
\text { Correlation }\end{array}$ & $-.093^{* *}$ & $.308^{* *}$ & 1 \\
\hline & Sig. (2-tailed) & .000 & .000 & \\
\hline & $\mathrm{N}$ & 2710 & 2710 & 2710 \\
\hline
\end{tabular}

Sumber: data diolah (2019) $\quad * *$. Correlation is significant at the 0.01 level (2-tailed).

\subsection{Faktor Kelulusan Tidak Tepat Waktu}

Informasi mengenai kelulusan mahasiswa S1 FMIPA Universitas Udayana menyatakan terdapat $19 \%$ mahasiswa tidak mampu menyelesaikan studinya tepat waktu. Untuk mengetahui faktor intelektual dari mahasiswa yang memengaruhi masa studi mahasiswa tidak tepat waktu, analisis dilakukan pada data mahasiswa yang lulus tidak tepat waktu. Sampel penelitian diambil secara purposive random sampling dengan pertimbangan kecukupan sampel mahasiswa dengan masa studi lebih dari lima tahun.

Matriks korelasi antar variabel penelitian pada (Lampiran. Matriks Korelasi Variabel Penelitian) menunjukkan hubungan linear antar variabel penelitian signifikan. Kelayakan data dianalisis dengan menggunakan analisis faktor didasarkan pada kriteria bahwa analisis faktor layak digunakan apabila nilai KMO lebih besar dari 0,50. Pada penelitian ini nilai KMO sebesar 0,760 maka analisis faktor layak digunakan.

Pembentukan faktor dalam analisis faktor dengan metode komponen utama. Banyak faktor yang dibentuk ditentukan berdasarkan banyak komponen dengan nilai eigen lebih besar atau sama dengan satu. Pada penelitian ini, terdapat dua komponen utama dengan nilai eigen lebih besar dari satu, sehingga ditentukan dua faktor intelektual yang memengaruhi kelulusan mahasiswa tidak tepat waktu. Penentuan variabel-variabel yang menyusun faktor dilakukan dengan rotasi varimax. Variabelvariabel intelektual mahasiswa yang menyusun kedua faktor diuraikan dalam Tabel 3.7. 
Tabel 3.7 Faktor Loading dan Komunalitas

\begin{tabular}{lrrr}
\hline Variable & Factor1 & Factor2 & Communality \\
\hline IPK & 0.757 & 0.573 & 0.901 \\
Total SKS & 0.322 & 0.771 & 0.698 \\
SMT1 & 0.714 & 0.173 & 0.540 \\
SMT2 & 0.774 & 0.185 & 0.633 \\
SMT3 & 0.817 & 0.217 & 0.715 \\
SMT4 & 0.713 & 0.234 & 0.563 \\
SMT5 & 0.496 & 0.523 & 0.519 \\
SMT6 & 0.208 & 0.766 & 0.630 \\
SMT7 & 0.107 & 0.693 & 0.492 \\
& & & \\
Variance & 3.2617 & 2.4287 & 5.6904 \\
\% Var & 0.362 & 0.270 & 0.632 \\
\hline Sumber: data diolah $(2019)$ &
\end{tabular}

Berdasarkan varibel-variabel yang menyusun faktor pertama, yaitu IPS pada semester 1, IPS semester 2, IPS semester 3, IPS semester 4, dan IPK, variabel-variabel ini menunjukkan kompetensi mahasiswa dalam penguasaan konsep-konsep dasar dan konsepkonsep lanjutan menuju bidang keahlian sebagai faktor pertama yang menentukan masa studi mahasiswa tidak tepat waktu. Faktor ini diberi nama sebagai faktor kompetensi pengetahuan mahasiswa. Faktor pengetahuan mahasiswa memiliki keragaman sebesar $36,2 \%$ dalam menentukan masa studi tidak tepat waktu. Hal ini mengindikasikan sangat penting membantu mahasiswa dalam adaptasi belajar dari sistem belajar di sekolah ke sistem belajar di Perguruan Tinggi yang banyak dituntut kemandirian dalam proses pembelajaran. Ketidakmampuan mahasiswa dalam menguasi satu konsep dasar atau pengetahuan dasar dapat mengakibatkan mahasiswa tidak mampu menguasai konsep dasar yang lain atau konsep lanjutannya.

Faktor kedua disusun oleh variabel-variabel IPS semester 5, IPS semester 6, IPS semester 7, dan total SKS. Varibel-variabel ini menunjukkan kompetensi mahasiswa pada ketrampilan yang diharapkan mampu dikuasai, mencakup keterampilan umum maupun ketrampilan khusus pada bidang keahlian. Faktor ini diberi nama faktor Ketrampilan, memberi keragaman sebesar 27\%. Kedua faktor intelektual ini menjelaskan keragaman sebesar $63,2 \%$ dari faktor-faktor yang memengaruhi masa studi mahasiswa S1 FMIPA Universitas Udayana. Sebanyak 36,8\% keragaman yang belum dijelaskan kedua faktor, dijelaskan oleh faktor intelektual lain dan faktor non intelektual yang belum dianalisis dalam penelitian ini.

\section{KESIMPULAN DAN SARAN}

\subsection{Kesimpulan}

Hasil analisis data menunjukkan bahwa kelulusan mahasiswa S1 FMIPA Universitas Udayana periode wisuda Januari 2002 hingga Januari 2019, sebanyak 2196 orang (81\%) mampu menyelesaikan studi tidak lebih dari 10 semester dan 514 orang mahasiswa (19\%) dengan masa studi lebih dari 10 semester. Mahasiswa perempuan cenderung lebih banyak mampu menyelesaikan studinya tepat waktu. Kelulusan mahasiswa S1 FMIPA berjenis kelamin laki-laki 1106 (40,8\%) dan 59,2\% perempuan. Ada perbedaan signifikan jumlah kelulusan mahasiswa dalam masa studi pada masing-masing program studi. Hal ini mengindikasikan adanya kebergantungan antara jumlah kelulusan dengan program studi, ada program studi tertentu dengan jumlah kelulusan mahasiswa S1 berbeda secara signifikan dengan program studi lainnya.

Analisis faktor eksploratori pada variabelvariabel intelektual mahasiswa menunjukkan terdapat dua faktor yang memengaruhi mahasiswa menyelesaikan studinya tidak tepat waktu, yaitu faktor pengetahuan dan faktor keterampilan. Kedua faktor intelektual ini menjelaskan keragaman data sebesar $63,2 \%$ dari faktor-faktor yang memengaruhi masa studi mahasiswa S1 FMIPA Universitas Udayana. Sebanyak 36,8\% keragaman belum dijelaskan kedua faktor, dijelaskan oleh faktor intelektual lain atau faktor non intelektual yang tidak dianalisis dalam penelitian ini.

\subsection{Saran}

Penelitian ini perlu dikembangkan untuk mengetahui faktor intelektual lain yang tergolong faktor afektif dan faktor non intelektual yang memengaruhi kelulusan mahasiswa tidak tepat waktu.

\section{UCAPAN TERIMA KASIH}

Terima Kasih mendalam diucapkan kepada pimpinan LP2M dan Universitas Udayana atas penelitian dengan dana DIPA BLU Universitas Udayana sesuai dengan Surat Perjanjian Kerja Pelaksanaan Kegiatan PUPS Nomor: 2026/UN14.2.8.II/LT/2019, tanggal 10 April 2019. 


\section{DAFTAR PUSTAKA}

Hair, J.F., Anderson, R.E., Tatham, R.L. and Black, W.C. 1995. Multivariate Data Analysis with Readings, 4th edition. Prentice-Hall, Inc., New Jersey.

Johnson, R.A and Winchern, D.W. 1998., Applied Multivariate Statistical Analysis. Prentice Hall International, Inc., USA

Pedoman Akademik. 2019. Fakultas Matematika dan Ilmu Pengetahuan Alam Universitas Udayana. Badung.

Permenristekdikti RI No. 44 Tahun 2015. Standar Nasional Pendidikan Tinggi juncto Permenristekdikti No 50 Tahun 2018 tentang Perubahan atas Permenristekdikti No. 44 Tahun 2015 tentang Standar Nasional Pendidikan Tinggi.
Permendikbud No 3 Tahun 2020 tentang Standar Nasional Pendidikan Tinggi.

Ridwan. 2008. Kegiatan Belajar dan Prestasi. (Online). http://ridwan-202.Wordpress. com/2008/04/23/kegiatan-belajar-danprestasi, diakses 10 Februari 2018.

Satiman, Hefri Asra, dan Omika. 2015. Peran Faktor Intelektual dan Non Intelektual dalam Belajar. (Online). https://infosos. wordpress.com/2015/03/07/peran-faktorintelektual-dan-non-intelektual-dalambelajar, diakses 8 Agustus 2019. 